\title{
THE EFFECT OF DIFFERENT STOCKING DENSITIES OF MARINE SHRIMP LARVAE Litopeneaus vannamei ON WATER QUALITY USING BIOFLOC TECHNOLOGY
}

\author{
Mervat A. M. Ali ${ }^{1}$, H. M. Khuraiba ${ }^{1}$, Nourhan E. G. Elsayed ${ }^{1}$ and Zaki Z. Sharawy ${ }^{2 *}$ \\ ${ }^{1}$ Faculty of Agriculture, Suez, Canal University, Egypt. \\ ${ }^{2}$ Invertebrate Laboratory, Aquaculture Division, National Institute of Oceanography and Fisheries, Suez, \\ Egypt. \\ * correspondance: zaki_sharawy@yahoo.com
}

(Received 25/11/2019, accepted 28/1/2020)

\section{SUMMARRY}

$\mathrm{T}$ here is a need to develop diets for shrimp cultured in Egypt in different rearing systems that will provide sufficient protein for shrimp production while minimizing the amount of nitrogen being introduced into the culture medium. Bioflloc technology (BFT) as the new application in keeping up good water quality and growth performance of shrimp cultured. The present experiment was conducted to investigate the effects of three different stocking densities and the carbon source (sugarcane bagasse) with biofloc and control system (commercial diet 38\% CP) in Litopeneaus vannamei on water quality. Shrimp were stocked with different densities in 18 tank at rate $(12,14$ and16 larvae/L) with water volume $150 \mathrm{~L}$ for 90 -days. Triplicate groups of shrimp $(0.002 \mathrm{~g})$ were fed three time daily at a ratio of $14 \%$ from body weight and adjusted gradually to $5 \%$ at the end of the experiment. The water quality parameters (temperature, salinity, $\mathrm{PH}$, total ammonia nitrogen (TAN), nitrites $\left(\mathrm{NO}_{2}\right)$, nitrates $\left(\mathrm{NO}_{3}\right)$, phosphate $\left(\mathrm{PO}_{4}\right)$, total suspended solid (TSS) and biofloc volume (BFV)) were suitable for culture of L. vannamei in different stocking densities in biofloc and control treatments. TSS and BFV was significantly higher in biofloc treatments compared to control and especially in the third stocking density (16 BF Larvae/L). Addition of sugarcane bagasse as carbon source into $L$. vannamei culture can effectively increase the activities of nitrogen cycle bacteria, which can reduce inorganic nitrogen levels and gradual increase both TSS and BFV.

Keywords: Litopenaeus vannamei, sugarcane bagasse, biofloc technology, water quality and shrimp culture.

\section{INTRODUCTION}

Aquaculture continues to pioneer the advancement of intensive cultivation technology in order to increase the production and to meet people's protein needs. Intensification has caused culture climate to deteriorate, disease outbreaks increased, and productivity reduced. Technologies which minimize the impact on the environment and the incidence of disease are therefore very much required. The use of various natural products in aquaculture as immunostimulants has been reported to be effective in reducing the evidence of disease in fish and shrimp aquaculture and increasing production (Manoppo et al 2015; Sharawy et al. 2020). More research has also focused on the use of medicinal plants and spices in order to prevent disease and promote growth such as ginger, garlic, etc. (Nya and Austin 2009; Manoppo et al 2016; and Payung et al 2017). Biofloc application is another promising alternative, and is still being developed. Biofloc systems are used in Indonesia for aquaculture of catfish, tilapia and shrimp, especially of Litopenaeus vannamei with high density (Azim and Little. 2008; Ekasari. 2009; and Hermawan et al. 2014).

Some definitions regarding the notion of biofloc technology have been put forward by some experts. Crab et al. (2012) stated that biofloc technology is a technique to improve the quality of water for aquaculture activities by adding carbohydrate sources externally through feed. According to Aiyushirota (2009), biofloc is a biological wastewater treatment that activates sludge, while Ekasari (2009) claimed that 
biofloc technology is the conversion of inorganic nitrogen, particularly ammonia, to microbial biomass by heterotrophic bacteria, which can then be consumed by cultivated organisms. Biofloc deals with waste that has the potential to harm the ecosystem that is continually generated by aquaculture activities with a high nutrient content (Riani et al. 2012).

Some factors that make biofloc systems more efficient compared to conventional systems include reducing feed use, preventing spread of disease by minimizing water changes that are environmentally friendly. Biofloc is critical for improving the quality of the water and preventing disease incidence (Choo and Caipang 2015; Nurhatijah et al. 2016). Cadiz et al (2016) found that the use of biofloc could control the presence of Vibrio sp. and Vibrio parahaemolyticus in intensive culture of $L$. vannamei. Therefore, biofloc can be applied at aquaculture with high densities (Hargreaves 2013). For general, protein is only consumed by about $20-25$ percent for fish feed, and the remainder will be secreted by waste and unfed food containing ammonia and organic nitrogen. To stimulate the growth of heterotrophic bacteria and turn inorganic nitrogen into microbial protein, manipulation of the $\mathrm{C}: \mathrm{N}$ ratio in aquaculture environments is needed (Avnimelech 1999).

The addition of carbon sources with an increase in the $\mathrm{C}: \mathrm{N}$ ratio can theoretically increase the conversion of toxic inorganic nitrogen species to microbial biomass available as food for cultivated animals. The optimum $\mathrm{C}: \mathrm{N}$ ratio in aquaculture systems can be maintained by adding a variety of cheap carbon sources or reducing protein content in feed (Avnimelech 1999; Hargreaves 2006). Biofloc utilization is urgently needed for environmentally friendly aquaculture production.

The major objective of the project is to evaluate the effect of different stocking densities of marine shrimp Larvae on water quality under the biofloc technology.

\section{MATERIALS AND METHODS}

Larvae of $L$.vannamei were obtained from a commercial shrimp hatchery in Burj Al-Arab, Alexandria, Egypt. Shrimps were transported in oxygenated double - layered polythene bags. When the shrimp arrived at the laboratory they were moved into the acclimation tank filled with seawater (salinity, $32 \mathrm{ppt}$ ). Initial samples were taken immediately after reaching larvae from hatchery, and final sample is taken from each tank at the end of experiment for chemical analysis. Prior to start of experiment, shrimps were acclimated to laboratory condition for two weeks and fed twice daily with commercial feed (38\% Crud Protein, $10 \%$ Lipid, 3.1\% Fiber, $19 \%$ carbohydrate).

The experiment was carried out in 18 tanks with water volume $150 \mathrm{~L}$ in the invertebrate laboratory, National Institute of Oceanography and Fisheries (NIOF), Suez, Egypt. Tanks were filled with Seawater after filtered by plankton net $(50 \mu \mathrm{m})$ to prevent the entry of unwanted materials and suspended particles into the tanks and was diluted with fresh water to achieve a salinity of (32 ppt). All tanks were supplied with 4 air stone-hoses type of diffuser system which is fitted to air-blower $(220 \mathrm{w})$. Aeration was provided 24 hours throughout the experiment for ensuring better bioflocculation. The biofloc was produced in one tank $(200 \mathrm{~L})$ using water from shrimp culture pond as an inocula growth according to Avnimelech, (1999) using sugarcane bagasse (SB) as carbon source. The suspension was incubated for two weeks for development of microbial communities. Proximate composition and organic carbon content in sugar bagasse were determined according to AOAC (1995) and Jackson (1967) respectively as shown in Table (1).

Table (1): The chemical analysis \% of sugarcane bagasse.

\begin{tabular}{lc}
\hline Parameters \% & Sugarcane bagasse(SB) \\
\hline Protein (\%) & 1.5 \\
Lipid (\%) & 1.5 \\
Ash (\%) & 7.6 \\
Fiber (\%) & 65 \\
Carbohydrate (\%) & 24.4 \\
Organic carbon $(\%)$ & 39.45 \\
\hline
\end{tabular}


All tanks were always covered with plastic sheet to reduce escapes of shrimp. In the tanks representing the control system treatments water was exchanged two time in week. While biofloc tanks were maintained for 90 days without any water exchange (zero water exchange), except to compensate for evaporation.

After two weeks, all tanks were stocked with shrimp larvae at three different stocking densities of shrimp (12, 14 and16 Larvae/L) in each tank (x3). Before stocking, we weighed the shrimp, and the initial body weight (Mean, $0.002 \mathrm{~g}$ ). Shrimp were fed with experimental diets at $14 \%$ from body weight and adjusted gradually to $5 \%$ at the end of the experiment. The daily feeding ration for each treatment was calculated and adjusted by estimating the biweekly sampled mean biomass. The ration was divided and distributed three times daily and Pre-weighed SB was completely mixed in a glass beaker with tank water sample and spread to tanks surfaces. In biofloc treatments, C:N ratio was maintained at 16:1 for activate bacterial growth which, however, approximately calculated based on carbon and nitrogen content of the daily feed input and the carbon sources addition in biofloc tanks.

To maintain water quality at optimum range for shrimps the following parameters were monitored during the experiment to follow the effect of biofloc system and comparison with control system.

Daily parameters: water temperature $\left({ }^{\circ} \mathrm{C}\right)$ was measured daily at $13: 00 \mathrm{~h}$, salinity and $\mathrm{pH}$ was measured daily at 10:00h using multiparameter analyzer.

Biweekly parameters: water sample $(100 \mathrm{ml})$ were collected from each tank and filtered by filter papers to analyze total ammonium nitrogen (TAN), total suspended solid (TSS), nitrite- $\mathrm{N}\left(\mathrm{NO}_{2}-\mathrm{N}\right)$, nitrate- $\mathrm{N}\left(\mathrm{NO}_{3}-\mathrm{N}\right)$ and phosphate-P $\left(\mathrm{PO}_{4}-\mathrm{P}\right)$ using spectrophotometer model (JENWAY 6100). Biofloc volume was estimated on a weekly basis using Imhoff cone, measuring biofloc volume in $1000 \mathrm{~mL}$ tank water after 15-20 min sedimentation (Avnimelech and Kochba, 2009).

All variables measured at water quality parameters to determine the effect of different stocking densities (12, 14 and 16 Larvae/L) on growth performance and effect of carbon source (sugarcane bagasse) under biofloc system. The ANOVA were performed using the SAS v9.0.0 (2004) program. The ANOVA was followed by Duncan test (1955) at $\mathrm{P}<0.05$ level of significant

\section{RESULTS AND DISCUSSION}

The daily water quality parameters such as temperature, salinity and $\mathrm{pH}$ monitored during the experimental period are shown in Table (2). Temperature, salinity and $\mathrm{pH}$ were at the optimum range for Litopenaeus vannamei cultured. They are shown in Figs (1), (2) and (3).

The biweekly water quality parameters; TAN, nitrite-N, nitrate-N, Phosphate, Total suspended solid (TSS) and Biofloc volume (BFV) are shown in Table (2). The biofloc development in terms of TSS and BFV over experimental period (90-days) are shown in Figs (8) and (9) respectively. Bioflocs were observed as brown color after the third week in all biofloc treatments, and were composed of suspended organic particles in the form of flocculated aggregates, which were colonized by a number of heterotrophic bacteria, microalgae and protozoa. In the biofloc treatments BFV and TSS ranging from7.8 \pm 4.66 to $9.4 \pm 4.67 \mathrm{ml} / \mathrm{L}$ and $284 \pm 58.9$ to $338 \pm 62.1 \mathrm{mg} / \mathrm{L}$, respectively. The effect of addition of the carbon sources in the experimental diets decreased total ammonia nitrogen (TAN), nitrite-N $\left(\mathrm{NO}_{2}\right)$, nitrate- $\mathrm{N}\left(\mathrm{NO}_{3}\right)$ and Phosphate $\left(\mathrm{PO}_{4}\right)$ that was ranging from, $0.01 \pm 0.01$ to $0.02 \pm 0.01,0.02 \pm 0.01$ to $0.03 \pm 0.03,0.021 \pm 0.007$ to $0.02 \pm 0.006$ and $0.30 \pm 0.12$ to $0.40 \pm 0.18$ in all biofloc treatments respectively. The results of total ammonia nitrogen (TAN), nitrite- $\mathrm{N}\left(\mathrm{NO}_{2}\right)$, nitrate- $\mathrm{N}\left(\mathrm{NO}_{3}\right)$ and Phosphate $\left(\mathrm{PO}_{4}\right)$ concentrations are shown in Figs (4), (5), (6) and (7) respectively. 
Ali et al.

Table (2): Effect of biofloc technology on the water quality (Mean \pm SD) in experimental tanks of $L$. vannamei under different stocking densities for 90 days.

\begin{tabular}{|c|c|c|c|c|c|c|}
\hline \multirow{3}{*}{ parameter } & \multicolumn{6}{|c|}{ Stocking densities } \\
\hline & \multicolumn{2}{|c|}{12 Larvae/L } & \multicolumn{2}{|c|}{14 Larvae/L } & \multicolumn{2}{|c|}{16 Larvae/L } \\
\hline & C & $\mathrm{BF}$ & C & $\mathrm{BF}$ & C & $\mathrm{BF}$ \\
\hline Temperature & $28.5 \pm 0.53$ & $28.4 \pm 0.47$ & $28.2 \pm 0.58$ & $28.3 \pm 0.57$ & $28.4 \pm 0.43$ & $28.3 \pm 0.57$ \\
\hline Salinity & $32.0 \pm 0.57$ & $32.7 \pm 0.44$ & $31.8 \pm 0.58$ & $32.6 \pm 0.55$ & $32.1 \pm 0.42$ & $32.7 \pm 0.44$ \\
\hline $\mathrm{PH}$ & $7.8 \pm 0.33$ & $7.9 \pm 0.21$ & $7.9 \pm 0.30$ & $7.9 \pm 0.23$ & $7.9 \pm 0.31$ & $7.9 \pm 0.39$ \\
\hline TAN & $0.03 \pm 0.012$ & $0.02 \pm 0.01$ & $0.02 \pm 0.01$ & $0.01 \pm 0.01$ & $0.03 \pm 0.01$ & $0.02 \pm 0.008$ \\
\hline NO2 & $0.03 \pm 0.02$ & $0.02 \pm 0.01$ & $0.04 \pm 0.03$ & $0.03 \pm 0.02$ & $0.04 \pm 0.03$ & $0.03 \pm 0.03$ \\
\hline NO3 & $0.022 \pm 0.008$ & $0.021 \pm 0.007$ & $0.03 \pm 0.01$ & $0.02 \pm 0.006$ & $0.03 \pm 0.01$ & $0.02 \pm 0.006$ \\
\hline $\mathrm{PO} 4$ & $0.36 \pm 0.13$ & $0.30 \pm 0.12$ & $0.43 \pm 0.20$ & $0.38 \pm 0.18$ & $0.44 \pm 0.21$ & $0.40 \pm 0.18$ \\
\hline TSS & $246 \pm 96.6$ & $284 \pm 58.9$ & $257 \pm 91.7$ & $299 \pm 96.3$ & $315 \pm 48.5$ & $338 \pm 62.1$ \\
\hline BFV & Zero & $7.8 \pm 4.66$ & Zero & $8.1 \pm 4.88$ & Zero & $9.4 \pm 4.67$ \\
\hline
\end{tabular}

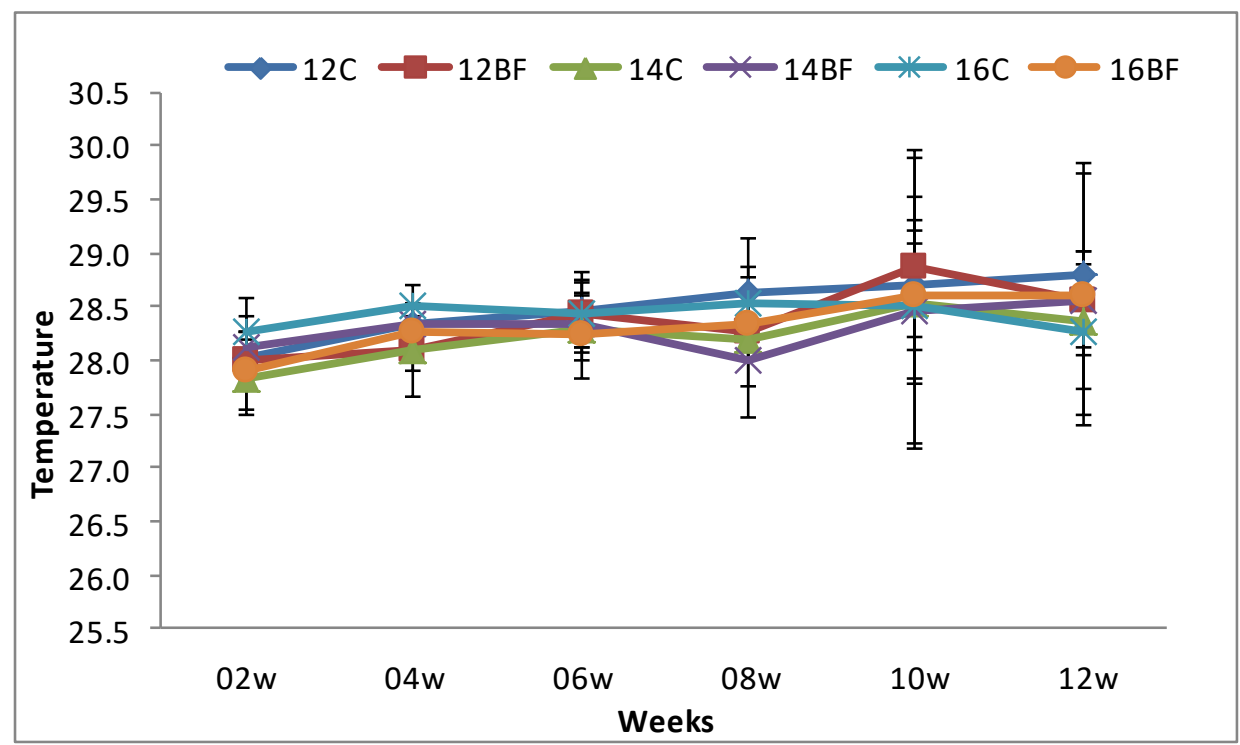

Figure (1): Effect of biofloc technology on temperature in experimental tanks of $L$. vannamei under different stocking densities for 90 days. 


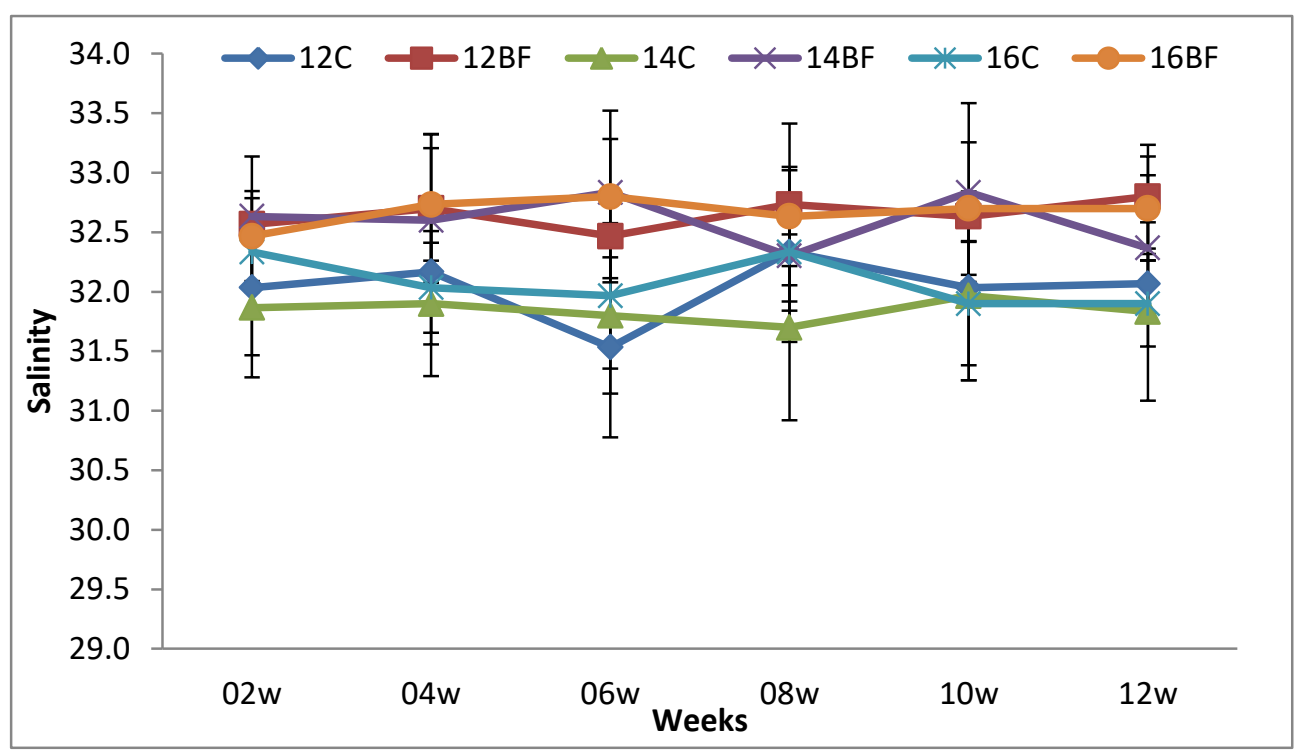

Figure (2): Effect of biofloc technology on salinity in experimental tanks of $L$. vannamei under different stocking densities for 90 days.

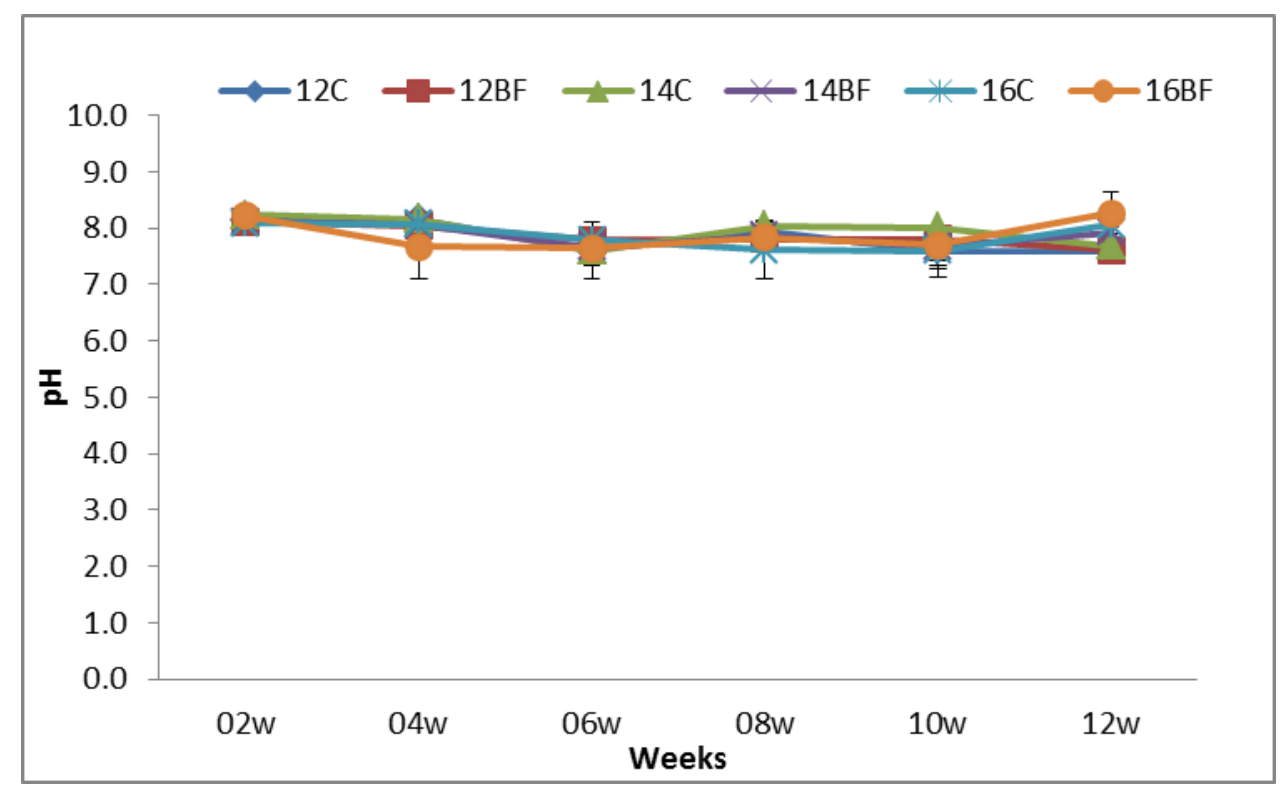

Figure (3): Effect of biofloc technology on PH in experimental tanks of $L$. vannamei under different stocking densities for 90 days. 
Ali et al.

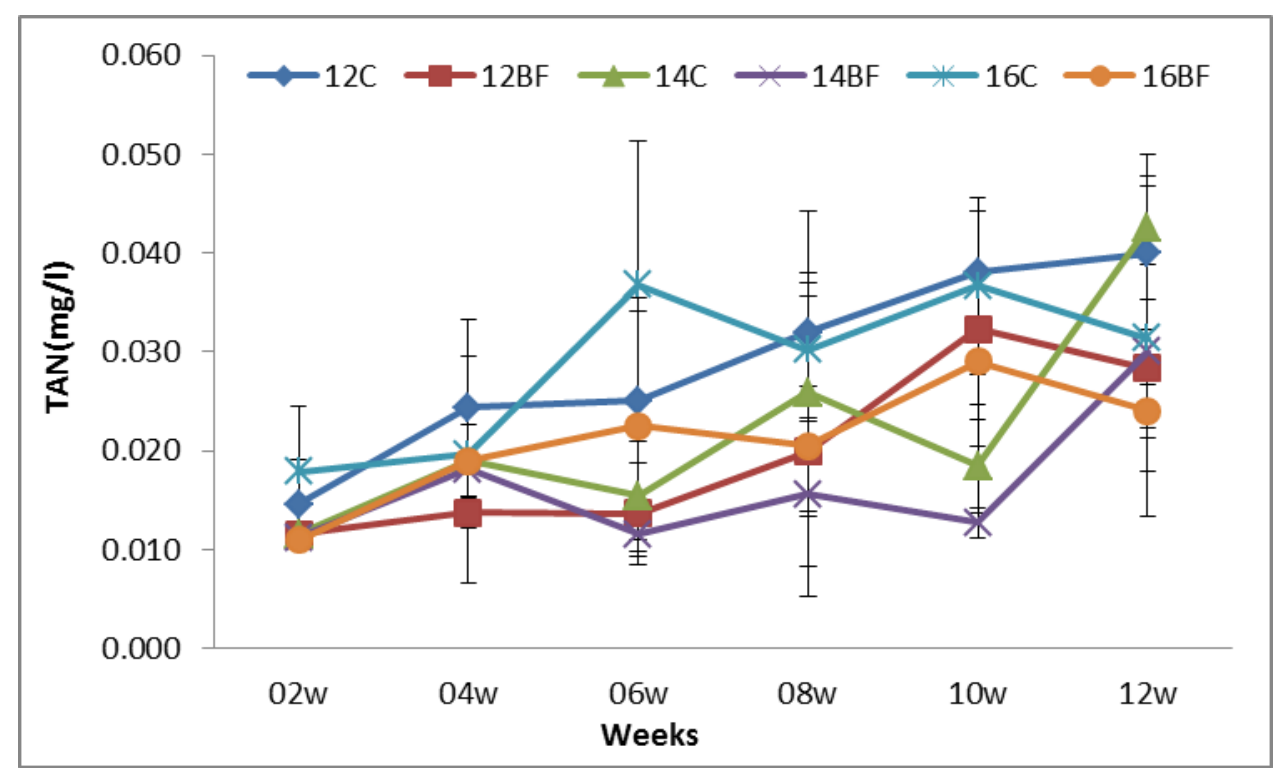

Figure (4): Effect of biofloc technology on TAN in experimental tanks of $L$. vannamei under different stocking densities for 90 days.

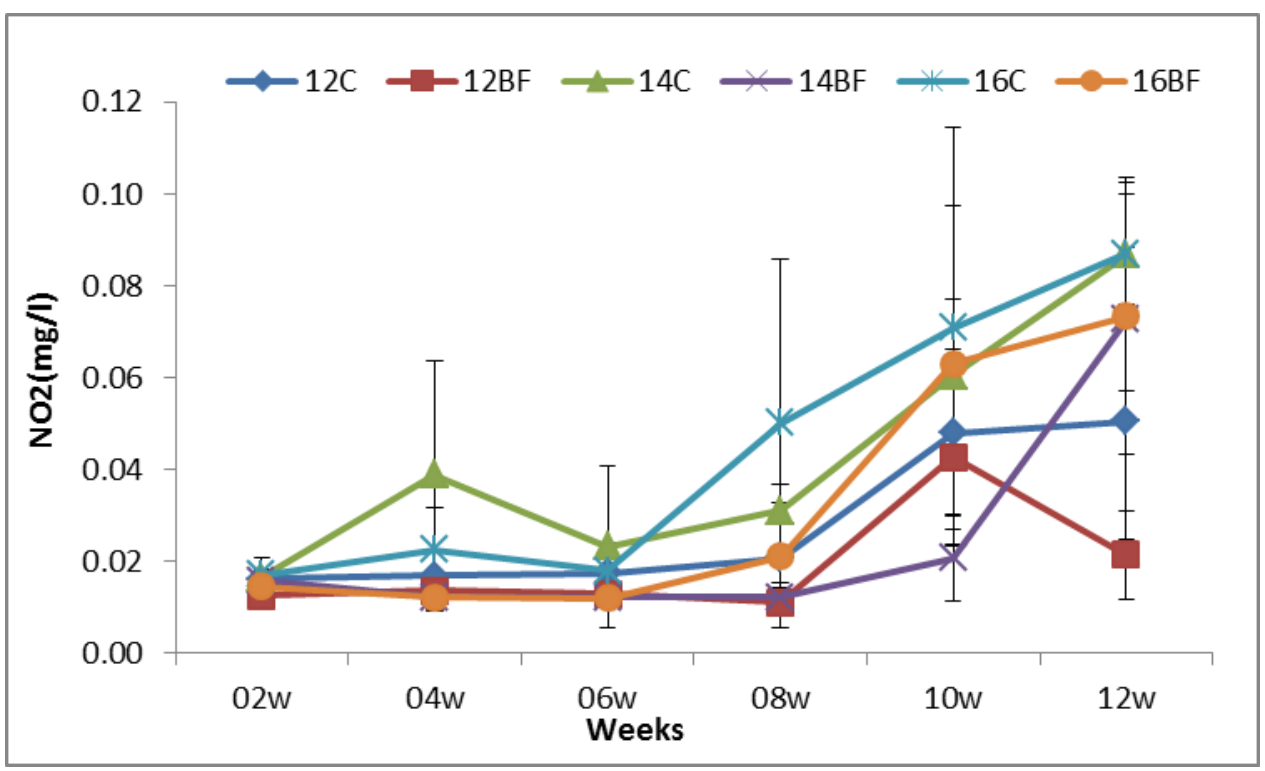

Figure (5): Effect of biofloc technology on $\mathrm{NO}_{2}$ in experimental tanks of $L$. vannamei under different stocking densities for 90 days. 


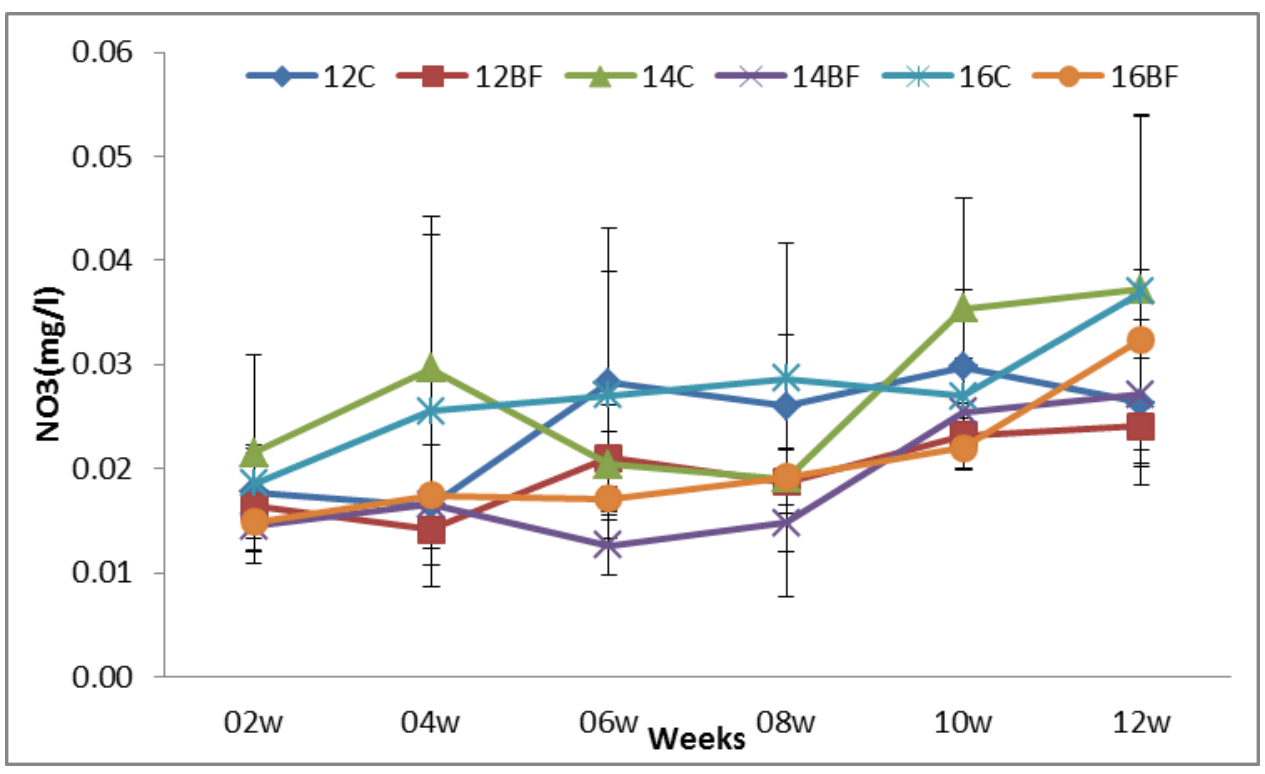

Figure (6): Effect of biofloc technology on $\mathrm{NO}_{3}$ in experimental tanks of $L$. vannamei under different stocking densities for 90 days.

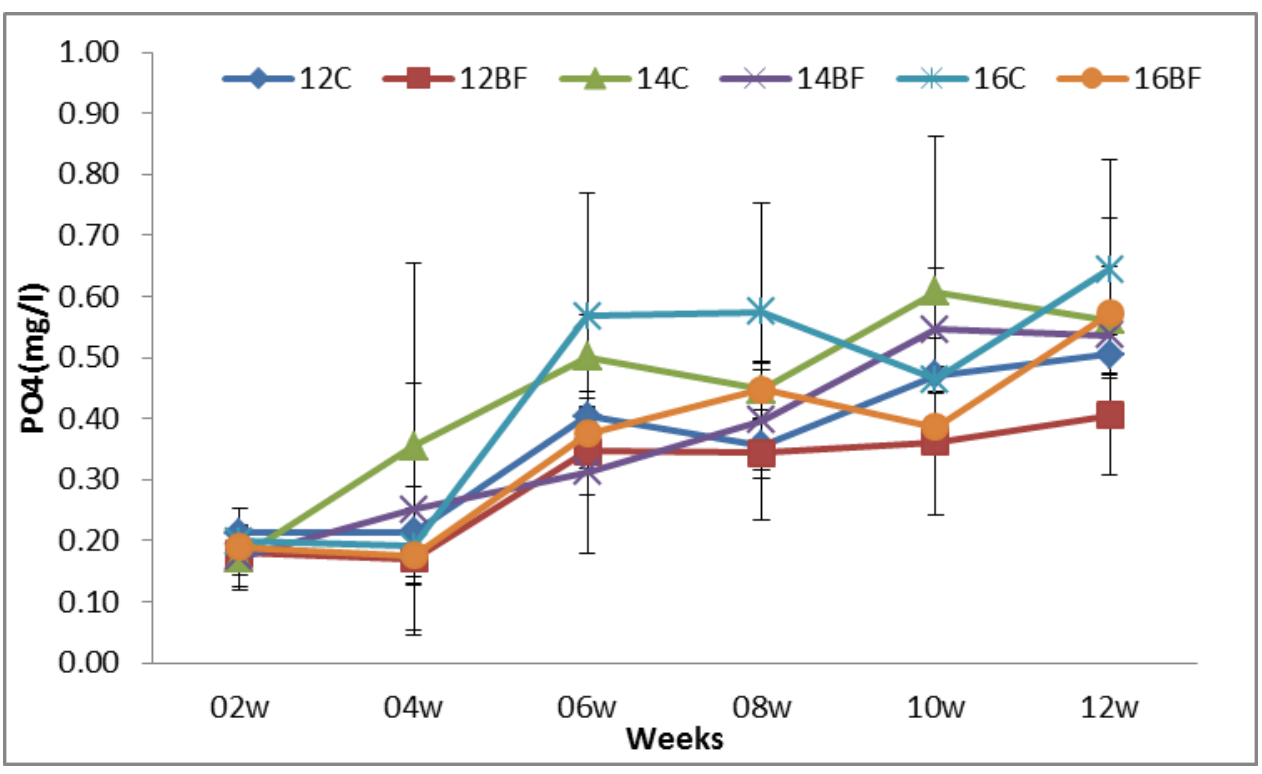

Figure (7): Effect of biofloc technology on PO4 in experimental tanks of $L$. vannamei under different stocking densities for 90 days. 


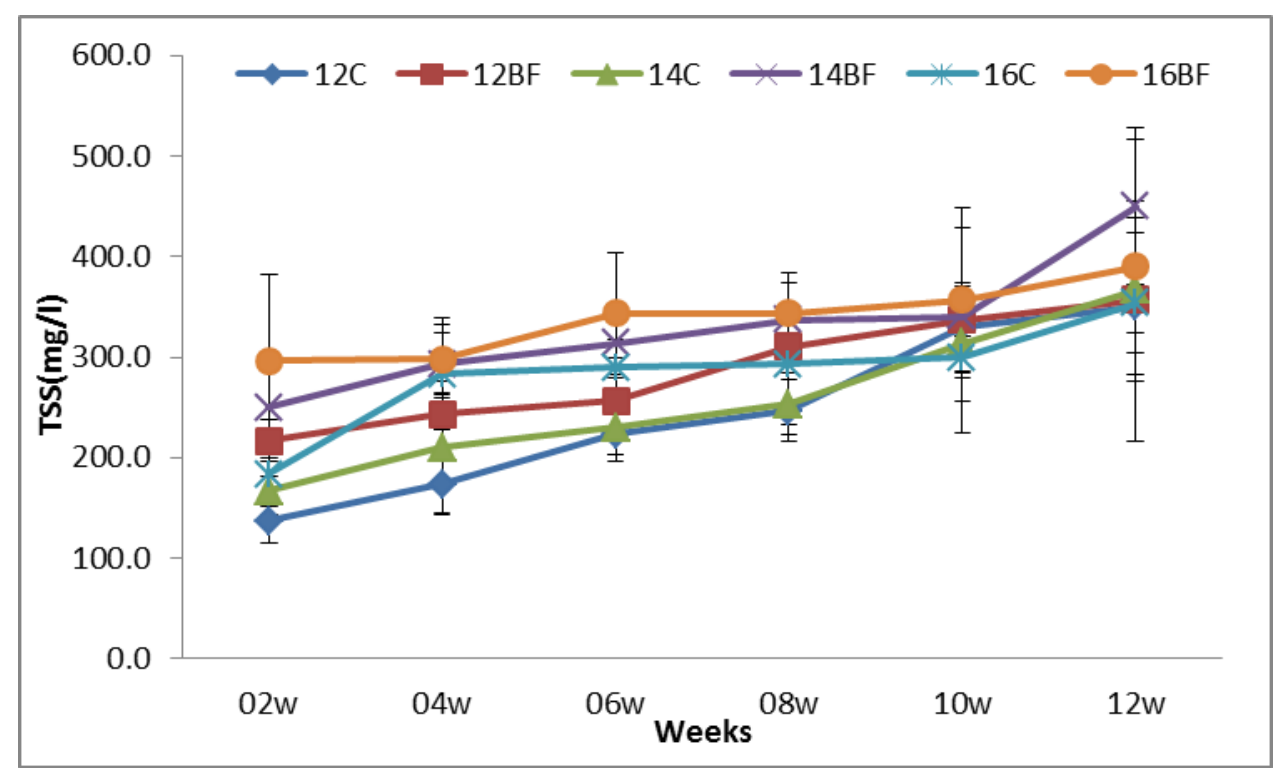

Figure (8): Effect of biofloc technology on development of TSS in experimental tanks of L. vannamei under different stocking densities for 90 days.

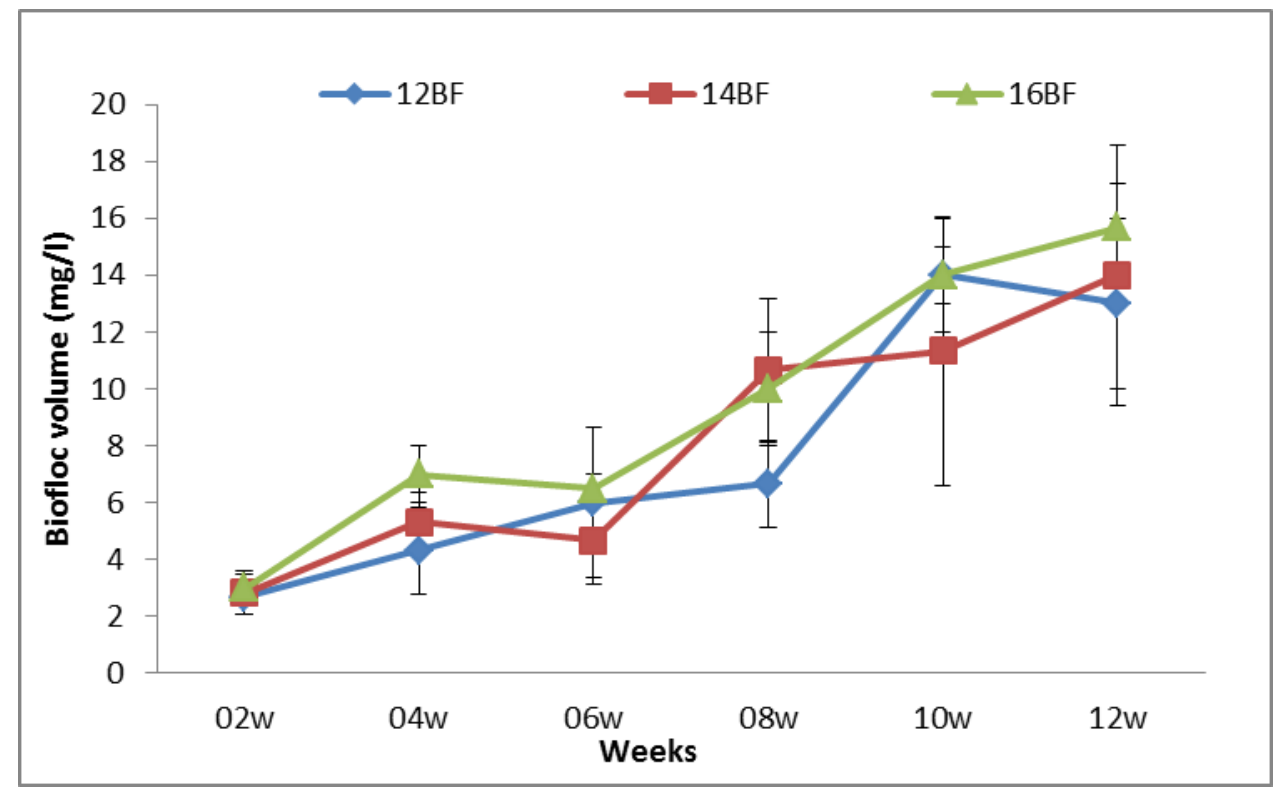

Figure (9): Effect of biofloc technology on the development of BFV in experimental tanks of $L$. vannamei under different stocking densities for 90 days.

Bioflocs technology aims to improve the quality of water in aquaculture systems by combining carbon and nitrogen with care. In this study, the impact of biofloc technology on white-leg shrimp (L. vannamei) under various storage densities (12, 14 and 16 Larvae/L) and one carbon source (sugarcane bagasse) was studied. During the experimental time (90 days), there was no significant difference in temperature and salinity between control and biofloc treatments and they were at the optimum range for L.vannamei cultivated (Wasielesky et al. 2013; Foes et al. 2011; krummenauer et al. 2011 and DaSilva et al. 2015). In temperate climate and in subtropical climate, L. Vannamei community is hit hard by low temperatures. Low temperatures can curb shrimp growth and cause death in the coldest months (Peixoto et al. 2003). In the treatment of bioflocs, the $\mathrm{pH}$ was unexpected, sometimes slightly below the range considered optimal, and 
then corrected for several times. In the present study, the $\mathrm{pH}$ values for penaeid shrimps were within the preferred range as cited by (Van Wyk and Scarpa, 1999). Increasing C:N ratio in the treatment of biofloc has resulted in a decrease in $\mathrm{pH}$ in these treatments due to the increased production of $\mathrm{CO} 2$ by higher biomass of heterotrophic bacteria (Xu et al., 2016).

Our results were supported by Hussain et al. (2015), who found that the increasing levels of the C:N ratios (16:1) in biofloc tanks have significantly influenced the values of $\mathrm{pH}$ during the culture period by keeping them more or less constant. This could be related to the presence of heterotrophic bacteria which consume organic matter and cause the increase in the level of water inorganic carbon $\left(\mathrm{CO}_{2}\right)$ and decrease the values of $\mathrm{pH}$. However, $\mathrm{pH}$ usually declines when the redox potential declines as a result of microbial activity (Ritvo et al., 1998). Ebeling et al. (2006), stated that nitrogen uptake by heterotrophic process that likely to dominate BFT system consumes alkalinity half than nitrification ( $3.57 \mathrm{~g}$ alkalinity $\left./ \mathrm{g} \mathrm{NH}_{4}{ }^{+}-\mathrm{N}\right)$. They also concluded that as alkalinity concentration relates to the buffering capacity of water, the effect of the high concentration of $\mathrm{CO}_{2}$ resulted from organisms cultured and microbial respiration on water $\mathrm{pH}$ could sufficiently buffered in BFT systems.

Avnimelech et al. (2012) reported that floc volume (FV) and total suspended solids (TSS) are the true indicators of biofloc formation. In the present study, the biofloc development in terms of biofloc volume (BFV) and total suspended solids (TSS) during the experimental period were kept within acceptable ranges and the biofloc treatments recorded significantly higher BFV and TSS compared to control. It was possible that sugarcane bagasse, a kind of a high fiber and slightly soluble substance, was poorly utilized by biofloc.

The present results were similar to that in Rajkumar et al. (2016) study, who found that TSS was within the recommended level of $<500 \mathrm{mg} / \mathrm{L}$ for penaeid shrimps (Samocha et al., 2007). Several authors have indicated that a similar trend of concentration of TSS which is beneficial to the shrimp and to the system stability (De Schryver et al.2008; Baloia et al., 2013).

The formation and development of the biofloc in the BFT treatments water was likely to be linked with the direct assimilation of dissolved nitrogenous matters (especially ammonia-nitrogen) from diets and shrimp excretions by heterotrophic bacteria (Avnimelech, 1999 ; Schneider et al., 2005; Ebeling et al., 2006), and simultaneously, over all water quality, especially low levels of TAN and $\mathrm{NO}_{2}-\mathrm{N}$, could be maintained within recommended range for shrimp culture due to the carbon source addition ( $\mathrm{Xu}$ et al., 2012).

In our results, the concentrations of TAN and $\mathrm{NO}_{2}$ at biofloc treatments were lower compared with control ( $\mathrm{p}<0.05$ ), which was also agreed with other researchers such as (Gaona et al., 2011). Studies have shown that the carbohydrate addition into the zero-water exchange system for shrimp culture can effectively increase the activities of nitrogen cycle bacteria, which can thus reduce inorganic nitrogen levels.

By adding carbohydrates to the water and regulating the $\mathrm{C}: \mathrm{N}$ ratio, the heterotrophic bacterial assimilation of nutrients, and the formation of biofloc could be optimized, consequently leading to the removal of TAN and NO2 (Avnimelech, 1999). The organic carbon source of choice will to a large degree determine the composition of the floc produced, considering the type and amount of storage polymers (De Schryver et al. 2008), and these finding is agreed with our results.

The community structure of biofloc and its development affect the microbial process of metabolite assimilation and nutrient cycling, creating different water quality dynamics in the culture system. In the present study, the effect of addition of carbon source in the experimental diets was significantly decrease the total ammonia nitrogen (TAN) and nitrite $\left(\mathrm{NO}_{2}\right)$ in all biofloc treatments. The concentration of TAN was significantly higher $(\mathrm{P}<0.05)$ in controls. Our results were supported by Wasielesky et al. (2013), who found that the concentration of total ammonia was maintained at low levels during the experiment which most likely resulting from the development of the microbial community that was established in the culture water.

Our results were found that TAN and $\mathrm{NO}_{2}-\mathrm{N}$ in the treatment without biofloc (control) on optimal ranges for $L$. vannamei, that due to change the water twice a week during the experimental period. These results suggested that once a mature biofloc community is established in the culture water, TAN and $\mathrm{NO}_{2}-\mathrm{N}$ concentrations can be effectively controlled by heterotrophic assimilation (e.g., TAN assimilation to nitrite and then to nitrate) maintaining them at acceptable ranges for shrimp culture.

The present results of TAN and $\mathrm{NO}_{2}$ concentrations at biofloc treatments were lower compared to the control $(\mathrm{P}<0.05)$, which was also agreed with other researchers such as (Gaona et al., 2011; Kuhn et al., 
2009; Wasielesky et al., 2013) observed that carbon supplementation enhanced the removal rates of TAN at $26 \%$ per hour compared to $1 \%$ per hour in a control system.

Hussain et al. (2015), found that concentration of ammonia and nitrite in the biofloc tanks decreased as the levels of C:N ratio (16:1) increased. This result implies that addition of carbon source had an obvious effect on the inorganic nitrogen reduction through stimulation of the bacterial growth.

Generally, the water quality parameters particularly ammonia, nitrite and total level of ammonia nitrogen are the primary limiting factors in the survivalability of shrimps (Santacruz Reyes and Chien, 2012). Better growth and survival may be due to the decreased production of toxic metabolites as a result of biofloculation in zero-or low water exchange system which is caused by adding organic carbon source to the system. So, addition of sugarcane bagasse significantly reduced the total ammonia nitrogen compared to control.

\section{ACKNOWLEDGEMENT}

The research was performed within EGY-DRAFT project (Development and Research Application of bioFloc Technology for increasing shrimp production in Egypt), which was financially supported, by the Science \& Technology Development Fund (STDF), Ministry of Scientific Research, Egypt. Agreement No. 25305/Reintegration Grants (STDF-RG) / STDF-Youth. The authors are grateful for all the support

\section{REFERENCES}

Aiyushirota, I. (2009). Heterotrophic bacteria system in shrimp culture with bioflocs. Biotechnology Consulting \& Trading, Indonesia,.

AOAC (1995). Official methods of analysis. In: Helrich K (ed) 15th edn. Association of Official Analytical Chemists, Virginia, p 1094.

Avnimelech, Y. (1999). Carbon and nitrogen ratio as a control element in aquaculture systems. Aquaculture 176: $227-235$.

Avnimelech, Y. (2012). Biofloc Technology - A Practical Guide Book (2nd edn). The World Aquaculture Society, Baton Rouge, Louisiana, USA 272pp.

Avnimelech, Y. and M. Kochba (2009). Evaluation of nitrogen uptake and excretion by tilapia in biofloc tanks, using N-15 tracing. Aquaculture, 287, 163-168.

Azim M. E. and D. C. Little (2008). The biofloc technology (BFT) in indoor tanks: water quality, biofloc composition, and growth and welfare of Nile tilapia (Oreochromis niloticus). Aquaculture 283:29-35.

Ballester, E.L.C., P.C. Abreu , R.O. Cavalli, M. Emerenciano, L. Abreu and W. Jr. Wasielesky (2010). Effect of practical diets with different protein levels on the performance of Farfantepenaeus paulensis juveniles nursed in a zero exchange suspended microbial flocs intensive system. Aquaculture Nutrition, $16,163-172$.

Baloia M., R. Arantes, R. Schveitzer, C. Magnotti and L. Vinatea (2013). Performance of Pacific white shrimp Litopenaeus vannamei raised in biofloc systems with varying levels of light exposure. Aquacultural Engineering, 52, 39-44.

Bratvold, D. and C.L. Browdy (2001). Effects of sand sediment and vertical surfaces (AquaMats TM) on production, water quality, and microbial ecology in an intensive Litopenaeus vannamei culture system. Aquaculture, 195:81-94.

Cadiz R. E., R. F. M. Traifalgar, R. C. Sanares, K. G. S. Andrino-Felarca and Jr. V. L. Corre (2016). Comparative efficacies of tilapia green water and biofloc technology (BFT) in suppressing population 
growth of green Vibrios and Vibrioparahaemolyticus in the intensive tank culture of Penaeus vannamei. AACL Bioflux 9 (2):195-203.

Choo H. X. and C. M. A. Caipang (2015). Biofloc technology (BFT) and its application towards improved production in freshwater tilapia culture. AACL Bioflux, 8(3):362-366.

Crab R., T. Defoird, P. Bossier and W. Verstraete (2012). Biofloc technology in aquaculture: beneficial effects and future challenges. Aquaculture, 356-357:351-356.

Da Silva, E. Da., J. Silva, F. Ferreira, M. Soares , R. Soares and S. Peixoto (2015). Influence of stocking density on the zootechnical performance of litopenaeus vannamei during the nursery phase in a biofloc system. bol. inst. pesca, são paulo, 41 (esp.): $777-783$.

De Schryver, P. D., R. Crab, T. Defoirdt, N. Boon, and W. Verstraete (2008). The basics of bio-flocs technology: the added value for aquaculture. Aquaculture, 277:125-137.

Duncan, D. B. (1955). Multiple range and Multiple Tests, Biometrics, 11:1- 42.

Ebeling, J.M., M.B. Timmons, and J. J. Bisogni (2006). Engineering analysis of the stoichiometry of photoautotrophic, autotrophic, and heterotrophic control of ammonia nitrogen in aquaculture production systems. Aquaculture, 257, 346-358.

Ekasari, J. (2009). Biofloc technology: theory and practical in intensive aquaculture system. Jurnal Akuakultur Indonesia 8(2):117-126. [in Indonesian]

Foes, G. K., C. Froes, D. Krummenauer, L. Poersch and W.Jr. Wasielesky (2011). Nursery of pink shrimp Farfantepenaeus paulensis in biofloc technology culture system: survival and growth at different stocking densities. J. Shellfish Res., 30:1-7.

Gaona, C.A., P.L. Poersch, D. Krummenauer, G.K. Foes and W.Jr. Wasielesky (2011). The effect of solids removal on water quality, growth and survival of Litopenaeus vannamei in a biofloc technology culture system. International Journal of Recirculating Aquaculture, 12, 54- 73.

Hargreaves J. A. (2006). Photosynthetic suspended-growth systems in aquaculture. Aquacultural Engineering, 34:344-363

Hargreaves J. A. (2013). Biofloc production system for aquaculture. Southern Regional Aquaculture Center, Publication factual sheet No: 4503, 12 pp.

Hermawan T. E. S. A., A. Sudaryono and S. B. Prayitno (2014). The effect of stocking density on growth and survival of catfish fingerling (Clarias gariepinus) in biofloc media. Journal of Aquaculture Management and Technology, 3(3):35-42.

Hussain, A., D.A. Mohammed, E.M. Ali and W.S. Sallam (2015). Growth performance of green tiger shrimp penaeus semisulcatus raised in biofloc systems. J Aquac Mar Biol., 2(5): 00038.

Jackson, M. L. (1967). Soil chemical analysis: advanced course. UW-Madison Libraries parallel press.

Krummenauer, D., R.O. Cavalli, L.H. Poersch and W.Jr Wasielesky (2011). Superintensive culture of white shrimp, Litopenaeus vannamei, in a biofloc technology system in southern Brazil at different stocking densities. J. World Aquacult. Soc., 42:726-733.

Kuhn, D.D., G.D. Boardman, A.L. Lawrence, L. Marsh and G.J. Flick (2009). Microbial flocs generated in bioreactors is a superior replacement ingredient for fish meal or soybean meal in shrimp feed. Aquaculture, 296, 51- 57.

Manoppo H., M. E. F. Kolopita and R. Malutunduh (2016). Growth promoter effect of garlic (Allium sativum) on carp (Cyprinus carpio L). International Journal of Pharm. Tech .Research, 9(4):283-288.

Manoppo H., U. N. Manurung and R. A. Tumbol (2015). Efficacy of baker's yeast as immunostimulant in Nile tilapia (Oreochromis niloticus). International Journal of Chem. Tech. Research8(2):559-565.

Nurhatijah N., Z. A. Muchlisin, M. A. Sarong and A. Supriatna (2016). Application of biofloc to maintain the water quality in culture system of the tiger prawn (Penaeus monodon). AACL Bioflux, 9(4):923928. 


\section{Ali et al.}

Nya E. J. and B. Austin (2009). Use of dietary ginger, Zingiber officinale Roscoe, as an immunostimulant to control Aeromonas hydrophila infections in rainbow trout, Oncorhynchus mykiss (Walbaum). Journal of Fish Diseases, 32:971-977.

Payung C. N., R. A. Tumbol and H. Manoppo (2017). Dietary ginger (Zingiber officinale) enhance resistance of Nile tilapia (Oreochromis niloticus) against Aeromonas hydrophila. AACL Bioflux, 10(4):962-968

Peixoto, S., W. Jr. Wasielesky, and L. Louzada (2003). Comparative analysis of pink shrimp, Farfantepenaeus paulensis, and pacific white shrimp, Litopenaeus vannamei, culture in extreme Southern Brazil. Journal of Applied Aquaculture, 14:101-112.

Rajkumar, M., P.K. Pandey, R. Aravind, A. Vennila, V. Bharti and C.S. Purushothaman (2016). Effect of different biofloc system on water quality, biofloc composition and growth performance in Litopenaeus vannamei (Boone, 1931). Aquaculture Research, 47(11):3432-3444.

Riani H., R. Rita and W. Walim (2012). Feed reduction effect on growth of vaname shrimp post larvae (Litopenaeus vannamei) given biofloc. Jurnal Perikanan dan Kelautan 3(3):207-212. [in Indonesian]

Ritvo, G., J.B. Dixon, A.L. Lawrence, T.M. Samocha, and W.H. Neill (1998). Accumulation of chemical elements in texas shrimp pond soils. J World Aquac soc., 29(4) :422-430.

Samocha, T.M., S. Patnaik, M. Speed, A.M. Ali, J.M. Burger, R.V. Almeida, Z. Ayub, M. Harisanto, A. Horowitz, and D.L. Brock (2007). Use of molasses as carbon source in limited discharge nursery and grow-out systems for Litopenaeus vannamei. Aquacultural Engineering, 36:184-191.

Santacruz Reyes, R.A. and Y.H. Chien (2012). The potential of yucca schidigera extract to reduce the ammonia pollution from shrimp farming. Bioresource Technology, 113: 311-314.

SAS (2004). Statistical Analysis System Institute. User's Guide: statistics. SAS Institute Inc., Cary.

Schneider, O., V. Sereti, E.H. Eding and J.A.J. Verreth (2005). Analysis of nutrient flows in integrated intensive aquaculture systems. Aquacultural engineering, 32(3-4): 379-401.

Sharawy, Z., Ashour, M., Abbas, E.M., Ashry, O.A., Helal, M.F., Nazmi, H., Kelany, M.S., Kamel, A., Hassaan, M., Waldemar Rossi Jr, Ehab El-Haroun and Ashraf Goda (2020). Effects of dietary marine microalgae, Tetraselmis suecica on production, gene expression, protein markers and bacterial count of Pacific white shrimp Litopenaeus vannamei. Aquaculture Research, 51(6): 2216-2228.

Van Wyk, P. and J. Scarpa (1999). Water quality requirements and management. Farming marine shrimp in recirculating freshwater systems. Florida Department of Agriculture and Consumer Services, Tallahassee, Florida, USA. Pages 128-138

Wasielesky, W.Jr., C. Froes, G. Fóes, D. Krummenauer, G. Lara and L. Poersch (2013). Nursery of Litopenaeus vannamei reared in a biofloc system: the effect of stocking densities and compensatory growth. Journal of Shellfish Research, 32(3), 799-806.

Xu, W.J. and L.Q. Pan (2012). Effects of bioflocs on growth performance, digestive enzyme activity and body composition of juvenile Litopenaeus vannamei in zero-water exchange tanks manipulating $\mathrm{C} / \mathrm{N}$ ratio in feed. Aquaculture, 356, 147-152.

Xu, W.J., T. C. Morris and T.M. Samocha (2016). Effects of C/N ratio on biofloc development, water quality, and performance of Litopenaeus vannamei juveniles in a bio floc-based, high-density, zeroexchange, outdoor tank system. Aquaculture, 453: 169-175

Xu, W.J., L.Q. Pan, X.H. Sun and J. Huang (2013). Effects of bioflocs on water quality, and survival, growth and digestive enzyme activities of Litopenaeus vannamei (Boone) in zero-water exchange culture tanks. Aquaculture Research, 44: 1093-1102. 
تاثير الكثافات التخزينية المختلفة ليرقات الجمبرى البحرى الفانمى على جودة المياه باستخدام تقنيه البيوفلوك

مرفت على محمد1 ، حافظ محمد خريبه1، ، نورهان السيد غريب السيد1 و زكى زكى شعراوى2"

\author{
1كلية النزراعة - جامعة قناة السويس بالاسماعيلية ـ مصر.

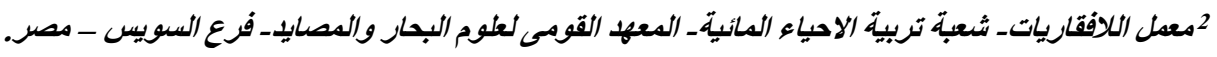

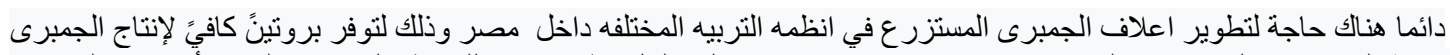

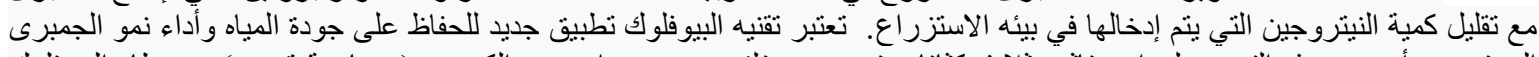

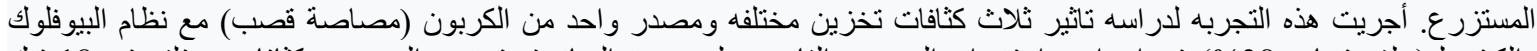

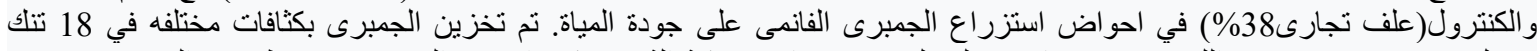

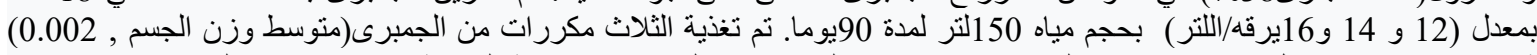

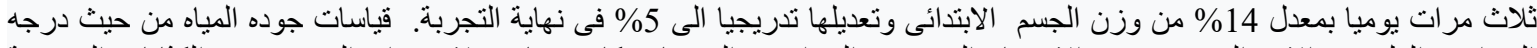

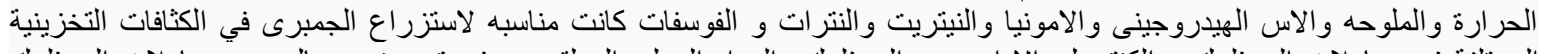

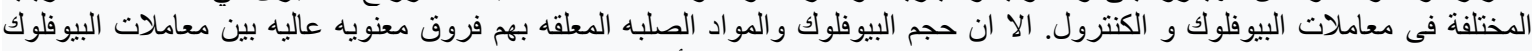

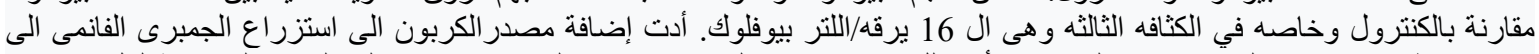

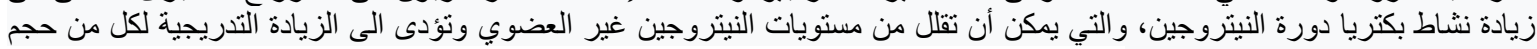

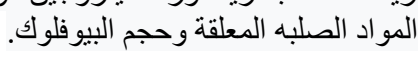

